\title{
JPEB
}

Jurnal Penelitian Ekonomi dan Bisnis, 5 (2), 2020, Hal: 162 -179

http://www.jpeb.dinus.ac.id

\section{THE ROLE OF DUALITY MANAGERIAL OWNERSHIP AND BOARDS ON IPO VALUE (AN EMPIRICAL EVIDENCE OF INDONESIAN FIRMS)}

\author{
Maximus Leonardo Taolin ${ }^{1 *}$, Julia Safitri ${ }^{2}$ \\ ${ }^{1}$ Department of Management, Faculty of Economics and Business, Timor University \\ Jalan Eltari km 9 Kefamenanu-Kupang TTU-NTT 85613, Indonesia. \\ 2 Sekolah Tinggi Ilmu Ekonomi IPWI Jakarta, Indonesia. \\ *Corresponding Author: mtaolin2@gmail.com
}

Received: February 2020; Revised: July 2020; Published: September 2020

\begin{abstract}
The research aims to find the impact of ownership retention, managerial ownership, and boards on value IPO premium and underpricing. We investigate by using hand collect data 202 IPO prospectuses during 2008-2017 and using Warp PLS 5.0 to compute the data. Our finding suggests that may use to guide the investor in making informed decisions to see the level of the proportion of sharehold by old ownership and management. When the high level of ownership retention and managerial ownership, make the value IPO premium and underpricing will be high. On the other hand duality of the managerial role in firms making the value will be achieved. This paper contributes to the value of IPO premium and underpricing literature when influence by ownership share on initial public offerings context of emerging markets.
\end{abstract}

Keywords: Ownership retention; Managerial Ownership; Boards; IPO premium; underpricing 


\section{INTRODUCTION}

Good Corporate Governance requires good management in an organization. According to Gul et al (2012) corporate governance mechanisms are mechanisms that protect the interests of shareholders. The corporate governance mechanism is a system that can provide protection and guarantees of rights to stakeholders, including shareholders, lenders, employees, executives, government, customers, and other stakeholders. According to Shleifer and Vishny (1997) corporate governance is a way or mechanism to convince capital owners to obtain an appropriate return or return from their investment. Yermack (1996) states that there are two indicators of the first corporate governance mechanism of internal corporate governance mechanisms proxied by the number of directors, the proportion of independent commissioners, and debt to equity. Second, the size of external corporate governance mechanisms proxied by institutional ownership.

In the perspective of agency theory, there is a conflict within the company due to the separation of ownership and control in the company. To reduce this conflict, it is indicated by the more concentrated ownership of a person or an institution, the stronger the control will be in the company. The relationship between ownership structure and firm value can be examined using the agency theory of (Jensen and Meckling, 1976). So that the greater the proportion of management ownership in the company, the management will try to improve its performance for the benefit of shareholders.

According to Chahine and Tohmé (2009), managerial ownership shows the dual role of a manager, with the dual role, the manager does not want the company to experience financial difficulties or even bankruptcy. This is because the manager will get a different impact on his position. As a manager he could lose the other side of the incentive as a shareholder he would lose his return or even lose his investment. This is done by the manager because the manager is the shareholder of the company. By increasing the company's performance, the greater the results obtained by the manager from the investment invested in the company. Managerial ownership is a situation where the manager has a share of the company or in other words the manager and owner or shareholder of the company.

In the statement, Yasser and Mamun (2015) the ownership structure has 2 (two) implications, namely (1) the structure of ownership of the state, institutions, and individual shareholders. (2) ownership concentration which comprises the percentage of ownership. The high concentration of ownership by some people will make a lack of coordination costs, (Dharwadkar et al, 2000). This is due to the small number of new owners. The other side Bruton et al (2010) argues that the concentration of ownership retained by the company owner at the time of the IPO is an important factor that can reduce agency conflicts that have an impact on its performance. So that it will reduce agency problems between agents and principals. Thus increasing the number of members in a council will be more effective in terms of supervision and monitoring. So that companies with a large board composition will display good performance volatility with a low risk of bankruptcy (Nakano and Nguyen, 2012). So that the greater the number of boards of directors shows the increasing effectiveness of supervision and monitoring in protecting the shareholders who retain their shares from the risk of failure during the IPO.

The Board is given the duties and responsibilities of supervising the management of the company and reporting everything related in the company to the board of commissioners. As a company organ, it is collegially responsible and responsible for managing the company. During the IPO process, the board of directors works and is responsible jointly to obtain good results, (Badru et al, 2017). In a previous study Darmadi and Gunawan (2013), emphasized the influence of the Board, managerial ownership, and old owner ownership on stock performance in cases in Indonesia. In other studies, Chahine and Goergen (2013) emphasized the role of the 
Board, managerial, and ownership of the value of premium IPOs. However, it does not identify the dual role of the manager as owner.

As a reference reinforces the reasons for this research, the gap between the numbers the board of directors and underpricing is used as a reference. Things done to see furthermore the role of the board of directors, the other side is in the management company, but the other side of the directors are shareholders and long-time owners to companies that will conduct an initial public offering on the capital market Indonesia. In other studies, the composition of the board has a negative effect on underpricing, (Certo et al. 2001). Then by Darmadi and Gunawan (2013) found that there was a negative relationship between board structure and level underpricing at the time of the initial sale of shares. Dolvin's research and Kirby (2016b) said that board size is negatively related significantly with underpricing. The other side Lin and Chuang (2011), said the composition of the board has the potential to increase underpricing and share performance first sales. This is supported by Hearn (2011) that the composition of the board directors is positively related to the level of underpricing. On the other hand inside Orphan research (2011) found no significant influence on the board of directors towards underpricing. Upon this gap, concepts will be formed which is expected to be able to explain the business phenomenon that occurs in research.

The gap from previous research can then lead the formation of a novelty that can bridge the research gap in research. Interestingly, there are differences in the number of directors in a company offering initial shares that have an underpricing value different, even though the company is engaged in a business line the same. The difference in underpricing is due to differences in information between market participants and owners or management within the company which made an initial public offering.

Become a universal phenomenon that underpricing occurs at each Initial public offering, (Escobari and Serrano, 2016). For listed companies, Underpricing will hurt them, because they fail to raise funds to the maximum, but profitable for investors (Rahim and Othman Yong 2010), because they get a profit (capital gain) from the price difference opening and closing. The underpricing phenomenon is a signal which gives a positive sign that the company is issuing initial shares has a probability of future profits. In Indonesia since the opening of the stock exchange, many companies have register (listing). The value of this underpricing is known through the trading first day on the trading floor. Ritter (1991), the difference in ratio between booking prices and closing is the initial return. As a universal phenomenon Underpricing is attractive to investors but this is detrimental to the issuer company during the first trading session. According to Maheshwari and Agrawal (2015) underpricing is a universal phenomenon that occurs in IPO whereas Overprice is a big concern when reducing investor prosperity. The issuer company listing in the capital market period 2010 to 2017, there were companies experiencing underpricing, 14 overpricing, and normal prices during the bidding process in the market secondary.

This phenomenon becomes interesting, because it is not only an underpricing event It can happen, but it can be overpriced in the offer of its shares. Grinblatt and Hwang (1989) say that the gap is informed investors and uninformed investors make share prices underpricing. As a result, Escobari and Serrano (2016), the group that did not get it good information will get overpriced shares in more portions large (uninformed investors). Whereas the group that receives information regarding the condition of the company, (informed investors) will buy shares in the primary market which are believed to be underpricing during the session secondary market closure. Here are 177 listed companies listing in the period 2010 to 2017, on the stock exchange Indonesia, which is experiencing underpricing and overpricing. 
Table.1 Listing companies on the IDX for the period 2010 to 2017

\begin{tabular}{rrrrrrrr}
\hline Tahun & $\begin{array}{r}\text { Emiten } \\
\text { IPO }\end{array}$ & \multicolumn{2}{c}{ \% Underpricing } & \multicolumn{2}{c}{ \% Wajar } & \multicolumn{2}{c}{ \% Overpricing } \\
\hline 2010 & 23 & 15 & $65 \%$ & 1 & $4 \%$ & 7 & $30 \%$ \\
2011 & 26 & 9 & $35 \%$ & 5 & $19 \%$ & 12 & $46 \%$ \\
2012 & 22 & 12 & $55 \%$ & 4 & $18 \%$ & 6 & $27 \%$ \\
2013 & 30 & 13 & $43 \%$ & 1 & $3 \%$ & 16 & $53 \%$ \\
2014 & 24 & 13 & $54 \%$ & 1 & $4 \%$ & 10 & $41 \%$ \\
2015 & 16 & 6 & $37 \%$ & 1 & $6 \%$ & 9 & $56 \%$ \\
2016 & 15 & 7 & $47 \%$ & 1 & $6 \%$ & 7 & $47 \%$ \\
2017 & 21 & 6 & $29 \%$ & 10 & $47 \%$ & 5 & $24 \%$ \\
Total & 177 & 81 & $45,76 \%$ & 24 & $13,56 \%$ & 72 & $40,68 \%$ \\
\hline
\end{tabular}

This study aims to see the effect of Ownership retention, Managerial Ownership, and Board on the value IPO premium of the company's. The difference with the previous research, that the sample in this study looked at the role of manager ownership as well as the owner of the company towards the IPO premium value and stock performance in the Indonesian capital market during the period 2008-2017.

\section{LITERATURE REVIEW}

\section{Ownership Retention and IPO value}

When including a subsection you must use, for its heading, small letters, 12pt, leftjustified, bold, Times New Roman as here. In Fan (2007), study, it was found that when a company owner who decides to have a greater proportion of shares in his company will be a signal that the company is of good quality, this supports the opinion Leland and Pyle (1977) the old owners risk maintain a higher proportion of ownership but this will have a good influence in the future for the company. According to Kuntara Pukthuanthong-Le and Walker (2008), for investors, the proportion of shares was disclosed in the IPO company's prospectus, and the stock price determination by the underwriter was seen as a promising signal in the future. This is getting a good signal, where investors will be interested in investing to provide long-term benefits.

Information regarding the large proportion of shares maintained by the company will be the main signal to assess the credibility of a company He et al (2015). According to Grinblatt and Hwang (1989) there are two main principles regarding the signal theory that must be known and observed before to the IPO and difficult to imitate by other companies that have lower IPO quality. Companies with lower IPO quality tend to try to sell as many IPO shares as possible to minimize the risk. Unlike companies with good IPO quality, it will try to maintain the proportion of its shares from the possibility of being controlled by other parties, (Yong Wang and Zhang 2015). The proportion of share ownership can be used as a tool to show or predict cash flows in the future. According to Leland and Pyle (1977) the proportion of share ownership can be used as a signal about the value of the company by the issuer. This is due to the assumption that the owner of the company will not release or diversify his portfolio if he is sure that his company has good prospects in the future (Wang and Iqbal, 2006). So that the old owner will maintain the level of ownership if believes the future cash flow is better than the current cash flow. Old shareholders and management will not release the proportion of ownership in the company if they are not sure of the success of the IPO, (Yong et al, 2015). So that the proportion of holdings held by old shareholders can be considered as factors that help build investor confidence in the success of the company's IPO. 
Furthermore, Fan (2007) found that this then gave birth to the assumption that the higher the level of ownership by the old owner (ownership retained by issuers), the higher the market valuation of the company's value, which was reflected in the performance of the stock itself. Leland and Pyle (1977) said that ownership retention can bring good cash flow in the future, then the cash flow only occurs during the IPO. Whereas in the long run ownership retention is one of the signals and one of the parameters, which in the long run in the market has various factors (Grinblatt and Hwang, 1989).

Keasey and McGuinness (1992) suggested that ownership retention by company owners at the time of the IPO had a positive impact on firm value. In the results of study Li et al (2005) said high retention rates attract more investor attention and provide quality assurance that increases the value of the IPO and its liquidity in the future. Where according to Cirillo, Romano, and Ardovino (2015) the IPO value reflects the potential value expected by investors from companies that conduct IPOs. Yasser and Mamun (2015), stated that the ownership structure has 2 (two) implications, namely (1) the structure of ownership of the state, institutions, and individual shareholders. (2) ownership concentration which comprises the percentage of ownership. Ownership of companies that conduct initial public offering (IPO), based on ownership by the old owner (ownership retention) which aims to expand the business. In the study Cirillo et al (2015), the percentage of family ownership as an old owner at the time of the IPO had a positive effect on the IPO Value. This happens because as owners of companies they come with a reputation for past success. Old owners always maintain the company's reputation in the eyes of investors that they have a responsibility to succeed in the IPO, (Mousa et al, 2014). The responsibility of the old owner is shown by the TMT (top management team) not only managing the IPO process but also directing the company's growth and negotiating the IPO price. With the retention rate by the old owner, it is assumed by investors that the owner wants the success of the IPO, so that the company's value becomes the quality reference, (Hull et al, 2013). With the ownership of a large owner will have a positive effect on the value of the IPO.

Based on all the statements and theoretical reviews above, a temporary conclusion can be given through the hypothesis

Hypothesis 1. Ownership retention during the IPO process has a positive effect on the value of the IPO.

\section{Ownership Retention and Underpricing}

There is also a liquidity theory which states that underpricing causes an increase in liquidity after the primary market (aftermarket) in the study of Li et al. (2005) there is direct evidence that the ownership of the old owner and underpricing has an influence that causes aftermarket share prices to increase. Li et al. (2005) found that the value of underpricing and ownership retention of companies is positively related and becomes an important variable in the decision of the initial public offering (IPO) as well (Leland and Pyle, 1977) argues that the proportion of share ownership held by the old owner (retained ownership) is wrong. one of the main factors in assessing IPO performance. Thus the proportion of shareholdings held by the old shareholders illustrates the level of management trust and the old shareholders will succeed in the IPO, (Fan, 2007), and (Leland and Pyle, 1977). Some of the reasons underlying this behavior are that when the old owners wanted good performance during the IPO, they retained a large number of shares, and when the initial bid managed to bring good performance, they also enjoyed the benefits, (Fan, 2007), Furthermore, after successfully raising funds for its investment plan, performance is no longer the concern of the old owners, where the price of shares on the secondary market has occurred according to market mechanisms, (He et al., 2015). The ownership by the old owner when the IPO becomes a good signal to investors about the quality of the issuer's company. The results of the research by (Leland and Pyle, 
1977) said that management behavior withholds shares when the IPO is a good signal of the quality of the company. The results of (Fan, 2007), the study found that ownership of shares by old owners had a positive effect on the level of underpricing and company performance in the primary market.

In this context, it can be said that ownership by the old owner and management can increase the value of underpricing. Ahmed et al (2011) said ownership by previous owners had a positive effect on the performance of IPO companies. Jain dan Kini (1994) in Ahmed S. Alanazi et al (2011) found that IPOs in America performed well when the owners retained their majority shares. But there are differences in the results of Darmadi and Gunawan (2013) research, finding that there is a negative relationship between old ownership and underpricing of an IPO. Through the results of previous studies, there are differences in the results of the research. This is shown that retention ownership by the old owners in the company has a positive effect on underpricing, (Carey et al. 2016).

Whereas (Boulton and Campbell, 2016) said that overhang shares or retain ownership of old owners have a positive effect on underpricing, this is then supported by, (Dolvin and Kirby, 2016). Likewise before, Handa and Singh (2015), the term promoter ownership was used as a variable that had a positive effect on the level of underpricing. According to Fan (2007) the old owner of the company (Ownership Retention) has a positive impact on the value of underpricing. The presence of high ownership retention will be a good signal for potential investors because they assume that the conflict between principals and agents occurs when the spread of ownership can be minimized (Darmadi and Gunawan, 2013). Based on all the statements and theoretical reviews above, a temporary conclusion can be given through the hypothesis

Hypothesis 2. Ownership retention during the IPO process has a positive effect on Underpricing.

\section{Ownership Managerial and IPO value}

In the perspective of agency theory, there is a conflict within the company due to the separation of ownership and control in the company, (Jensen and Meckling, 1976). To reduce this conflict, it is indicated by the more concentrated ownership of a person or an institution, the stronger the control will be in the company. Likewise, the greater the proportion of management ownership in a company, the management will try to improve its performance for the benefit of shareholders, (Mohd-Rashid et al, 2016). Managerial ownership shows the dual role of a manager.

With this dual role, managers do not want companies to experience financial difficulties or even bankruptcy. This is because the manager will get a different impact on his position. According to Chahine and Goergen (2013) ownership structure has a positive effect on IPO Value. Some previous research shows a positive relationship between ownership structure and firm value, where high managerial ownership will encourage the effectiveness of monitoring so that there is a convergence between the goals of managers and shareholders. Eugene F Fama and Jensen (1983) statement that the existence of large and concentrated ownership can control managerial performance. Chahine and Goergen (2013) Ownership structure have a positive effect on the value of the IPO. Whereas in the managerial context, ownership of family managers has a positive effect on the value of the IPO, (Cirillo et al. 2015).

Ownership structure has a positive effect on the value of IPO, in the previous study, Leitterstrof dan Rau (2014), Field dan Sheehan (2004) Jaskiwicz et al (2005), found that managerial ownership was positively related to the formation of firm value during the IPO. Increasing high managerial ownership can encourage exploitation by majority shareholders against minority shareholders, so that this will be responded to by the public in the form of a decrease in the company's IPO value. However, high managerial ownership can encourage 
better monitoring activities so that the expected conflict between management and shareholders is reduced, which increases in the company's IPO value.

As a manager he could lose the other side of the incentive as a shareholder he would lose his return or even lose his investment. This is done by the manager because the manager is the shareholder of the company. By increasing the company's performance, the greater the results obtained by the manager from the investment invested in the company. Managerial ownership is a situation where the manager has a share of the company or in other words the manager and owner or shareholder of the company. In high managerial ownership can encourage better monitoring activities so that the expected conflict between management and shareholders is reduced, which has an impact on increasing the value of the company. But on the other hand, an increase in high managerial ownership can encourage the exploitation of the majority shareholders of minority shareholdings, so that this will be responded to by the public in the form of a decrease in company value.

Hypothesis 3. Managerial ownership during the IPO process has a positive effect on IPO Value.

\section{Ownership Managerial and Underpricing}

According to Jensen and Meckling (1976) the perspective of agency theory, there is a conflict within the company due to the separation of ownership and control in the company. To reduce this conflict, it is indicated by the more concentrated ownership of a person or an institution, the stronger the control will be in the company. Likewise, the greater the proportion of management ownership in a company, the management will try to improve its performance for the benefit of shareholders. The reason that high managerial ownership can encourage better monitoring activities so that the expected conflict between management and shareholders is reduced, which has an impact on increasing the value of the company.

Managerial ownership shows the dual role of a manager, (Salloum Charbel, 2013). With this dual role, managers do not want companies to experience financial difficulties or even bankruptcy. This is because the manager will get a different impact on his position. As a manager he could lose the other side of the incentive as a shareholder he would lose his return or even lose his investment. This is done by the manager because the manager is the shareholder of the company, (Michel et al, 2014). By increasing the company's performance, the greater the results obtained by the manager from the investment invested in the company. Managerial ownership is a situation where the manager has a share of the company or in other words the manager and owner or shareholder of the company,(Djerbi and Anis, 2015).

According to the study Jigao et al (2016), said that managerial ownership affects the performance of IPO companies. This is as stated by Yong Wang and Zhang (2015) that the proportion of share ownership by managers has a positive effect on underpricing. In the context of ownership of previous managers Howton, and Olson (2001) and Su (2004) found that managerial ownership has a positive effect on underpricing, and Nikbakht et al (2007) which states that CEO ownership has a positive effect on the level of underpricing.

Hypothesis 4. Managerial ownership at the time of the IPO process has a positive effect on underpricing

\section{Relationship of the Boards to the Value of the IPO and Underpricing}

In agency theory, the emergence of a conflict of interest is due to the separation of company ownership and control. This conflict comes from differences in perspectives and interests between shareholders (principals) and managers (agents), (Eugene F Fama and Jensen, 1983). So that a good monitoring mechanism is needed to control and harmonize the interests of shareholders and managers, (Jensen and Meckling, 1976). In the limited company law article 97, it is stated that the commissioner has to supervise the policies of the board of 
directors in running the company and advising the directors. The Board of Commissioners as a corporate organ is collectively responsible and responsible for supervising and advising the board of directors and ensuring that the company carries out good corporate governance. According to the National Commission on Governance Policy (KNKG, 2006) it is defined as a corporate organ that is collectively responsible and responsible for supervising and advising directors and ensuring that the company carries out Good corporate governance. The greater the number of commissioners will provide a lot of input and supervision to be done better.

For the implementation of the duties of the board of commissioners to be effective, it is necessary to fulfill the following principles:

1. The composition of the board of commissioners must enable decision making effectively, precisely and quickly, and can act independently

2. Members of the board of commissioners must be professional, namely with integrity and ability so that they can carry out their functions properly including ensuring that the board of directors has taken into account the interests of all stakeholders.

3. The supervisory and advisory functions of the board of commissioners include preventive actions, repairs, to temporary dismissals.

In the Indonesian Corporate Governance Forum (FGCI, 2001), the characteristics of companies in the Indonesian capital market embrace two-tier board systems wherein the board structure is divided into duties and executive functions (board of directors) and supervisory functions (board of commissioners). The size and composition of the board of directors are following the company's strategy, during the IPO (Badru et al., 2017). Meanwhile, according to Darmadi and Gunawan (2013) the characteristics of corporate governance are seen from the board structure and ownership structure in the company.

In the study of Bennedsen et al 2008) the greater the size and composition of the board of directors will have a positive impact on the performance and value of the company. Bennedsen et al (2008) noted the performance and value of the company will increase if the composition of the board of directors is dominated by people from outside the company, but on the contrary, it will decrease if the board of directors comes from the company itself. This opinion is supported by $\mathrm{Xu}$ (2012) that the IPO value has a positive correlation with the composition of the company's board of directors and the IPO value has a significant effect. Where managerial board involvement is instrumental in increasing the value of new companies (Mousa et al, 2014). Bennedsen et al (2008) stated that the size and composition of the board of directors will have a positive impact on the performance and value of the company whose composition is dominated by the board of directors from outside the company and vice versa the performance and value of the company become low when the size and composition of the board of directors come from within the company itself. There are differences in the results of Darmadi and Gunawan (2013) research finding that there is a negative relationship between the board structure and the level of underpricing at the time of the IPO, which is following the opinion Certo, Covin, Dalton, and Daily (2001) that the composition of the board has no relationship with stock performance in its initial sales. This contradiction by Hermalin and Weisbach (2003) the number of small directors is more effective than a large number of directors because it reduces agency costs and members can play a more free role in the organization. However, if the number of councils is too large it will cause problems of coordination and communication and a high salary burden. The board of commissioners plays an important role in the implementation of the company's operational activities and reduces agency problems between managers and shareholders. Referring to the preliminary statement above, Yatim (2011), said that one of the signals of supervision and quality of good performance in a company is indicated by the mechanism of the board of directors and the board of commissioners protecting the ownership structure through the proportion of ownership. 
This mechanism is carried out as the implementation of corporate governance within the company. In previous studies, it was found that the composition and number of board of directors had a negative effect on the value of underpricing, (Yermack, 1996) and (Eisenberg et al, 1998). Then reinforced by the results of Sasongko and Juliarto (2014) and Purwanto et al (2015), it turns out that the greater the number of commissioners will have a negative influence on underpricing. Likewise, Darmadi and Gunawan (2013) said that there was a negative relationship between the board structure and the level of underpricing during the IPO.

Dalton et al (1999), said that one important factor in the implementation of effective corporate governance is the size of the board. Where the greater the number of commissioners in the company's board structure will increase effective supervision of the performance of the company's management. The large composition of the board of commissioners in the company is used as a signal for the quality of the company to the public, (Barroso-Castro et al, 2017). This can be shown by the increasing number of commissioners that show better corporate governance. The amount of the board of commissioners in a company will increase effective supervision of the company's performance Cirillo et al (2015), said that the involvement of managers can increase the IPO value of Issuer companies, this supports the opinion (Certo et al, 2003) that the existence of managers provides positive signal quality to investors about the quality of IPOs that affect the value of the IPO. Likewise, the more diverse the number of boards in an IPO company is the signal associated with the magnitude of the IPO Value (Zimmerman, 2008). Where the involvement of the board of directors at the time of determining the initial stock price has a positive effect on the value of the IPO company, (Mousa et al., 2014).

Hypothesis 5. The number of Boards at the time of the IPO process has a negative effect on the Premium IPO Value.

Hypothesis 6. The number of Boards at the time of the IPO process has a negative effect on underpricing

\section{RESEARCH METHODS}

\section{Sample and data collection}

In this study using a data panel that is a combination of time series data and crosssection 202 companies that conduct initial public offerings on the Indonesia stock exchange for the period 2010 to 2017. All data is collected manually from the IPO prospectus, which contains the bid price, closing price, structure of managerial ownership, ownership retention, board, listed companies. Data comes from Bloomberg, Yahoo Finance, Indonesian Capital Market Directory (ICMD), and IDX statistics as well as through relevant secondary publications that are indirectly obtained through online media in the form of records of company events or company historical reports. which are arranged in the company's archives listed on the Indonesian stock exchange.

\section{Statistical and variable measurement}

Based on time-series data and cross-section 202 companies that made the initial offering, this research used WarpPLS5.0 software to estimate the research model described by 3 (three expectoratory variables) and 2 control variables.

Specifically, this is a research model. 


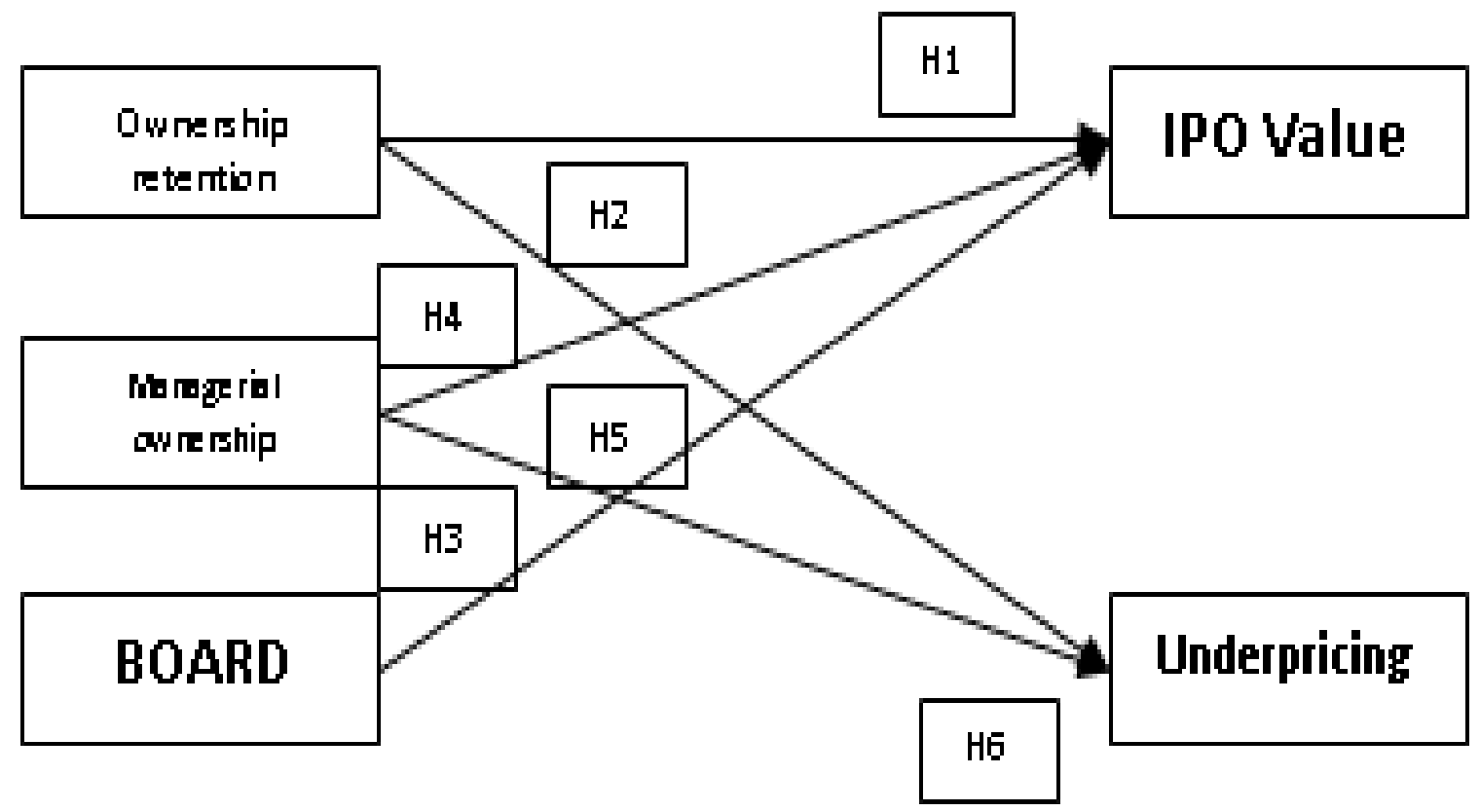

Figure 1. Summary of the Hypothesis

$$
\begin{gathered}
\text { IPO value }=\beta_{0}+\beta_{1}(\text { Ownership Retention })+\beta_{2}(\text { Managerial Ownership }) \\
\left.+\beta_{3} \text { (board }\right)+\delta_{1}(\text { control variable })
\end{gathered}
$$

\section{Dependent variable}

Mousa, Marlin, and Ritchie (2013) use premium IPO as a proxy for measured of the IPO value. The premium IPO is used as a proxy with the reason that the IPO value is the offering price which is reduced by the book value and then divided by offering price. Where the book value is the initial book value of the share price announced through the prospectus. The formulation of the value of the IPO (Premium IPO) is also used by Certo et al. (2003), (Chahine \& Goergen, 2013) (Mousa et al., 2013) dan (Cirillo et al., 2015).

$$
\text { IPO Premium }=\frac{\text { Offering Price }- \text { Book value }}{\text { Offering Price }}
$$

Whereas Darmadi and Gunawan (2013) calculated underpricing with the stock price formulation closing the first day of trading on the secondary market minus the sales price and then divided the sales price. Based on previous research on underpricing, for this research follows, (Darmadi \& Gunawan, 2013) and (Samarakoon, 2010), with the formulation as below;

$$
U P=\frac{P_{i l}-P_{i 0}}{P_{i 0}}
$$

\section{Independent variable}

Referring to the previous research, Djerbi and Anis (2015) measured ownership retention as the proportion of shares held by an insider (management and director) after the IPO. While in the study Fan (2007), the measurement of the number of shares held (ownership 
retention/alpha $(\alpha)$ is the total number of shares held by the old ownership before the offerings period, minus the number of shares in the offerings period then divided by the total number of shares after the offerings period as done, (Downes, and Heinkel, 1982; Feltham, et al., (1991),(Fan, 2007) Furthermore, it can be explained by the following formula (Li et al., 2005) and (Yong Wang \& Zhang., 2015).

$$
\frac{\text { total number of shares held by the old ownership (pre - IP0) }}{\text { total number of shares (post - IPO) }}
$$

Managerial ownership in this study was measured by the percentage of managerial ownership in IPO companies, (Deb, 2014) (Sasongko \& Juliarto, 2014) and (Filatotchev \& Bishop, 2002), (Elston \& Yang, 2010) as well (Elston \& Yang, 2010).In this case, the measurement of the board of this study follows Darmadi and Gunawan (2013) namely the Board size is the Natural Logarithm of the Board

\section{Control Variable}

Company size can be in the form of human resources, the total number of boards, and the total assets of the company. Through total assets, the company can give a signal that companies that have large assets will have good prospects. Total assets or also called assets are economic resources owned by the company and still provide benefits in the future. According to Leone, Rock, and Willenborg (2007), the size of the company (Ln Total assets) has a negative influence on the value of underpricing. Furtermore, Mnif. (2010), that the size of the company at the time of the IPO was negatively related to underpricing. In contrast, in the research, Ahmed S. Alanazi et al. (2011) found that the size of the company had a positive influence on the company's performance but was not significant. Then by Zhou and Lao (2012) using the firm size in Ln total assets has a positive effect on underpricing. Based on previous research on company size, this dissertation research follows, (Zhou \& Lao, 2012), (Ahmed S. Alanazi et al., 2011) (Mnif. 2010), which uses Ln total assets for Company Size.

\section{RESULT AND DISCUSSION}

Table 2. Operationalization of Research Variables

\begin{tabular}{ll}
\hline \multicolumn{1}{c}{ Vependent variable } & \multicolumn{1}{c}{ Operationalization } \\
IPO Premium & $\begin{array}{l}\text { Offering price on the first trading day on the } \\
\text { primary market minus book value of share divided } \\
\text { by Offering price } \\
\text { Closing price on the first trading day on the } \\
\text { secondary market minus offer price divided by the } \\
\text { offer price }\end{array}$ \\
$\begin{array}{l}\text { Share ownership } \\
\text { Ownership retention }\end{array}$ & $\begin{array}{l}\text { The Proportion of common shares held by the } \\
\text { managerial team } \\
\text { Bumber of people serving on the board's } \\
\text { Board Size }\end{array}$ \\
Firm Size & $\begin{array}{l}\text { commissioners and Directors } \\
\text { Logarithms natural Total asset of firms IPO }\end{array}$ \\
\hline
\end{tabular}


Table 3. Description of Statistical

\begin{tabular}{lrrrrr}
\hline Variable & $\begin{array}{r}\text { Number of } \\
\text { observation }\end{array}$ & Mean & Max & Min & SD \\
\hline IPO Premium & 202 & 0.43 & 0.89 & 0.57 & 0.34 \\
Underpricing & 133 & 0.33 & 0.87 & 0.034 & 0.25 \\
Ownership retention & 202 & 0.56 & 0.92 & 0.30 & 0.35 \\
Managerial & 201 & 0.66 & 0.96 & 0.23 & 0.31 \\
Ownership & & & & & \\
Board Size & 202 & 8 & 28 & 4 & 3 \\
\hline
\end{tabular}

Based on the table above it can be seen that the Managerial Ownership Variable in the company during the period after listing in 2008-2017 on average was 0.96 , which means $66 \%$, the average for all companies in this study sample was Managerial Ownership. This will mean that management has a shareholding in the company for decision making. The standard deviation of 0.56 in the variable $(\mathrm{OM})$ managerial ownership shows that there is an ownership bias of $56 \%$ or the presence of other dominant ownership in the company. A minimum value of 0.23 means that there is still a managerial party that has shares at the company. This is due to the characteristics of companies that are not public but state ownership. The maximum value is $96 \%$ indicating that there is managerial ownership in the company that makes the first listing on the capital market.

In the variable OR (ownership retention) an average owner is holding for up to 0.56 or $56 \%$ of the shareholding when the company is listing in the Indonesian capital market. It is also known that the standard deviation value is 0.1274 , which means that $12.74 \%$ of shares occur in the bias that is not owned by the old owner of the average overall shares outstanding when the company makes a listing. The minimum value of shares held is 0.30 or $30 \%$ and a maximum of 0.92 or $92 \%$ which is the highest percentage of the old owner retains its shares when the company makes initial public offerings.

Based on the table above it can also be seen that the boards in the company during the period after listing in 2008-2017 on average were 8 people in one company with a standard deviation of 3 on the variable boards. The minimum value of 4 which means some companies employ 4 people as a board. The maximum value is 28 indicating that there are companies that employ up to 28 board members in companies that do the initial listing on the capital market.

\section{Correlation Analysis}

Table 4. Correlation

\begin{tabular}{lcccccc}
\hline Correlation & $\mathbf{1}$ & $\mathbf{2}$ & $\mathbf{3}$ & $\mathbf{5}$ & $\mathbf{5}$ & $\mathbf{6}$ \\
\hline IPREM & 1 & & & & & \\
UP & $0.314^{* * *}$ & 1 & & & & \\
OR & $0.227^{* * *}$ & $0.133^{* * *}$ & 1 & & & \\
OM & $0.169^{* * *}$ & $0,135^{* * *}$ & $0.178^{* *}$ & 1 & & \\
LBOARDS & $0.253^{* *}$ & $0.060^{* *}$ & $0.165^{* * *}$ & $0.227^{* * *}$ & 1 & \\
LSIZE & $0.179^{* * *}$ & $0.040^{* * *}$ & $0.162^{* * *}$ & $0.169^{* * *}$ & $0.169^{* * *}$ & 1 \\
\hline P. value & \multicolumn{7}{l}{ Notes: significance at $: 10, * * 5$, and $* * * 1$ Percent levels } \\
\hline
\end{tabular}

In table 4 , it can be seen that the ownership retention variable is positively correlated with the variable IPO, Underpricing with a correlation coefficient of $0.227 * * *$, and $0.133 * * *$ then Managerial Ownership (OM) is positively correlated with the Variable IPO Value, Underpricing with a correlation coefficient of $0.169 * * *$ and $0.135 * * *$. The measurement of 
variable Boards is positively correlated with the variables of IPO Value, and Underpricing with a correlation coefficient of $0.253 * *$ and $0.060 * *$

\section{Result of Warp PLS 5.0 Analysis}

Table 5. The Goodness of Fit of the Structural Model

\begin{tabular}{lr}
\hline Criteria & Parameter \\
\hline Average path coeffisient $(A P C)$ & $\mathbf{0 . 2 6 6 * *}$ \\
Average $R$ Squared $($ ARS $)$ & $\mathbf{0 . 2 8 7 * *}$ \\
Average adjusted $R$ Squared (AARS) & $\mathbf{0 . 2 5 2 * *}$ \\
Average block VIF $($ AVIF) & $\mathbf{1 . 0 9 9}$ \\
Average Full Collinearity VIF (AFVIF) & $\mathbf{1 . 1 7 5}$ \\
Tenenhaus GoF (GoF) & $\mathbf{0 . 4 3 2}$ \\
Sympson's paradox ratio (SPR) & $\mathbf{0 . 8 8 9}$ \\
R squared contribution ratio (RSCR) & $\mathbf{0 . 9 8 3}$ \\
Statistical suppression ratio (SSR) & $\mathbf{0 . 8 3 6}$ \\
Notes: significance at $: * 10, * * 5$, and $* * * 1$ percent levels of confident
\end{tabular}

By looking at the test results of the goodness of fit model in the table above it can be explained that in this research model has a good and acceptable fit/fit where the P-Value APC, ARS $<0.005$. Whereas in testing the multicollinearity problem between exogenous variables, the AVIF value is 1,099 and the AFVIF value is 1,175 which 303.30 in this case, means that there is no multicollinearity among exogenous variables. Furthermore, for the predictive strength of the Tenenhaus GoF (GoF) model, it produces a value of $0.432(\geq 0.36)$ which means that the predictive power of this model is very strong and acceptable.

In measuring the causality problem in the research model with Sympson's paradox ratio (SPR), producing a value of $0.889(\geq 0.7)$ is still acceptable because the ideal value is 1 . Then to find out that the research model is free from the contribution of negative $\mathrm{R}$ squared can be seen from the R-value squared contribution ratio (RSCR) which yields a value of 0.983 where $\geq 0.9$ with the ideal value is 1 .

The next test is the problem of statistical suppression where a path coefficient has a large value when compared to the correlation path that connects two variables. Testing of statistical suppression impacts resulted in a Statistical suppression ratio (SSR) value of 0.836 which was $\geq 0.7$. in this case the model is free from the statistical suppression effect problem (Latan and Ghozali 2016). Seeing the results of the testing of goodness of fit this research model has good suitability. These results indicate that the results of the suitability evaluation of this model are in accordance with the support of available observation data.

Table 6. A Result of Structural Model Evaluation

\begin{tabular}{lrrrr}
\hline Description path & $\begin{array}{r}\text { Path } \\
\text { Coefficient }\end{array}$ & Adj.R $^{\mathbf{2}}$ & Q2 & Effect size \\
\hline OR $\rightarrow$ IPREM & $\mathbf{0 . 2 1 8 * * *}$ & 0.167 & 0.196 & 0.253 \\
OM $\rightarrow$ IPREM & $\mathbf{0 . 1 6 5 * * *}$ & & & 0.231 \\
LBOARDS $\rightarrow$ IPR & $\mathbf{- 0 . 0 8 9 * *}$ & & & 0.198 \\
EM & $\mathbf{0 . 2 3 1 *}$ & & & 0.765 \\
LSIZE $\rightarrow$ IPREM & $\mathbf{0 . 1 4 5 * * *}$ & 0.261 & 0.290 & 0.289 \\
OR $\rightarrow$ UP & $\mathbf{0 . 1 2 1} * * *$ & & & 0.180 \\
OM $\rightarrow$ UP & $\mathbf{- 0 . 1 5 5 * *}$ & & & 0.167 \\
LBOARDS $\rightarrow$ UP & $\mathbf{0 . 1 7 7 * *}$ & & & 0.130 \\
LSIZE $\rightarrow$ UP & & & & \\
\hline
\end{tabular}

Notes: significant at $: * 10, * * 5$, and $* * * 1$ percent levels of confident 
Based on the picture and table 6 shows the path coefficients and $p$ values for each direct effect between variables that have a positive effect. The relationship between Ownership retention variables to Premium and Underpricing IPO values is $0.218 * * *$ and $0.145 * * *$. This result supports Leland and Pyle (1977) and (Darmadi \& Gunawan, 2013) statement, that the ownership of the old owner gives an impression of the quality and prospects of the company in the future. Managerial Ownership (OM) of IPO Value and Underpricing (UP) shows coefficient value, $0.165 * * *$ and $0.145 * * *$, These results confirm the research Chahine and Goergen (2013) and Mousa et al. (2014) that there is a dual managerial role as Owner will increase Underpricing. while the Board Number has a significant negative coefficient on IPO Value and Underpricing. This confirms the study, Darmadi and Gunawan (2013) that the number of boards in the company does not affect the performance of its shares. This is due to the addition of board members, by investors considered symbolic and not effective in decision making.

To see the variations that affect the Premium IPO value can be seen in the adjusted $R$ squared value of 0.167 which means that the influence of variations in Ownership retention (OR) managerial ownership (OM), and Boards, Company size (LSIZE) on premium IPO value is The remaining $16.7 \% 83.3 \%$ is explained by other variables not included in this research model. If you see the rule of thumb for structural model evaluation in this study it can be categorized as weak, where the adjusted $R$ squared value is 0.167 less than $(\leq 0.25$ weak category).

Adjusted R squared values for variations in the effect of retention Ownership (OR) Managerial Ownership (OM), boards, and Company size (LSIZE) on underpricing (UP) of 0.261 or $26.1 \%$, the remaining $73.9 \%$ are explained by other variables not included in the model this research. If you see the rule of thumb for structural model evaluation in this study it can be categorized as moderate, where the adjusted $\mathrm{R}$ squared value of 0.261 is greater than $(>0.25$ moderate category).

As a reference for testing whether the Premium IPO Value variable has predictive relevance, it can be seen in the table above that the Q squared value is $0.196(>0)$, which means the model has predictive relevance which, if you see the rule of thumb, structural model evaluation resulting from premium IPO Value variables including in the moderate category where $(\mathrm{Q} 2 \geq 0.15)$. While the $\mathrm{Q}$ squared value generated underpricing variable (UP) is equal to $(0.290>0)$, which means the model has predictive relevance. If you look at the rule of thumb, the structural model evaluation resulting from underpricing (UP) variables is in the moderate category where $(\mathrm{Q} 2 \geq 0.15)$.

The effect size value is required that the independent variable has a very weak, weak, moderate or strong influence on the practical point of view even though it has a significant $\mathrm{p}$ value. It can be seen that the effect size of Ownership retention on the Premium IPO Value of 0.25 means having an effect size in the medium or moderate category from a practical point of view. It can be seen that for the effect size the Managerial Ownership (OM) of underpricing (UP) is $0.060(<0.15)$, which means having an effect size in a small category or a practical point of view. Furthermore, the influence of board variables on Underpricing (UP) results in an effect size value of $0.167(<0.15)$ indicating that there is no effect size. This means that the influence of the board on Underpricing (UP) is very weak from a practical point of view (practical point of view even though it has a significant $p$-value value. The effect size value influences the Company Size variable or total assets (LSIZE) against underpricing (UP) 0.130 $(<0.15)$ gives a variable meaning it has a weak or small effect size category from a practical point of view even though it has a significant $\mathrm{p}$-value. 


\section{CONCLUSION}

This study utilizes ownership retention, managerial ownership, and Boards variables that affect the value of premium IPOs in listing companies in the Indonesian capital market. the more ownership retention increases will increase the value of the company along with the increase in stock prices at the close of the first trading day. The dual role of the management has the effect of increasing the level of Premium and Underpricing IPO values. Ownership retention makes investors place perceptions of the commitment and quality of IPO companies. This appreciation can be seen from the increase in the stock price from its expectations.

\section{REFERENCES}

Ahmed S. Alanazi, Liu, B., \& Forster, J. (2011). The financial performance of Saudi Arabian IPOs. International Journal of Islamic and Middle Eastern Finance and Management, 4(2), 146-157,. doi: 10.1108/17538391111144533 10.1108/00021461311321311

Badru, B. O., Ahmad-Zaluki, N. A., \& Wan-Hussin, W. N. (2017). Board Characteristics and the Amount of Capital Raised in the Malaysian IPO Market. Journal of Multinational Financial Management. doi: 10.1016/j.mulfin.2017.09.001

Barroso-Castro, C., Villegas-Perinan, M. M., \& Dominguez, M. (2017). Board members' contribution to strategy: The mediating role of board internal processe. European Research on Management and Business Economics, 23, 82-89. doi: 10.1016/j.iedeen.2017.01.002

Bennedsen, M., Kongsted, H. C., \& Nielsen, K. M. (2008). The causal effect of board size in the performance of small and medium-sized firm. Journal of Banking \& Finance(32), 1098-1109. doi: 10.1016/j.jbankfin.2007.09.016

Boulton, T. J., \& Campbell, T. C. (2016). Managerial confidence and initial public offerings. Journal of Corporate Finance, 37(375-392). doi: 10.1016/j.jcorpfin.2016.01.015

Bruton, G. D., Filatotchev, I., Chahine, S., \& Wright, M. (2010). Governance, ownership structure, and performance of IPO firms: the impact of different types of private equity investors and institutional environments. Strategic Management Journal, 31(5), 491509. doi: $10.1002 / \mathrm{smj} .822$

Certo, S. T., Covin, J. G., Dalton, D. R., \& Daily, C. M. (2001). Wealth and The Effects of Founder Management Among IPO-Stage New Ventures. Strategic Management Journal, 22, 641-658. doi: 10.1002/smj.182

Certo, S. T., Daily, C. M., Jr, A. A. C., \& Dalton, D. R. (2003). Giving Money to Get Money: How CEO Stock Options and CEO Equity Enhance IPO Valuations. The Academy of Management Journal, 46(5), 643-653.

Chahine, S., \& Goergen, M. (2013). The effects of management-board ties on IPO performance. Journal of Corporate Finance, 21, 153-179. doi: 10.1016/j.jcorpfin.2013.02.001

Chahine, S., \& Tohmé, N. S. (2009). Is CEO Duality Always Negative? An Exploration of CEO Duality and Ownership Structure in the Arab IPO Context. Corporate Governance: An International Review, 17(2), 123-141.

Cirillo, A., Romano, M., \& Ardovino, O. (2015). Does family involvement foster IPO value? Empirical analysis on Italian stock market. Management Decision, 53(5), 1125 -1154.

Dalton, D. R., Daily, C. M., Johnson, J. L., \& Ellstrand, A. E. (1999). Number of Directors and Financial Performance: A Meta-Analysis. Academy of Management Journal, 42(6), 674-686.

Darmadi, S., \& Gunawan, R. (2013). Underpricing, board structure, and ownership. Managerial Finance, 39(2), 181 - 200. 
Deb, P. (2014). Cutting The 'Gordian Knot': Director Ownership, Underpricing, And Stock Liquidity In IPO Firms. Journal Of Managerial Issues:, xxvi(2), 130-156.

Dharwadkar, R., George, G., \& Brandes, P. (2000). Privatization in Emerging Economies: An Agency Theory Perspective. The Academy of Management Review, 25(3), 650-669. doi: $10.2307 / 259316$

Djerbi, C., \& Anis, J. (2015). Boards retained ownership and failure risk of French IPO firms. Corporate Governance, 15(1), 108 - 121.

Dolvin, S. D., \& Kirby, J. E. (2016). The Impact of Board Structure on IPO Underpricing. The Journal Of Private Equity, 15-21.

Eisenberg, T., Sundgren, S., \& Wells, M. T. (1998). Larger Board Size and Decreasing Firm Value in Small Firms. Journal of Financial Economics, 48, 35-54.

Escobari, Diego, dan Alejandro Serrano. 2016. "Reducing asymmetric information in venture capital backed IPOst." Managerial Finance no. 42 (6):553 - 568.

Elston, J. A., \& Yang, J. J. (2010). Venture capital, ownership structure, accounting standards and IPO underpricing: Evidence from Germany. Journal of Economics and Business, 62(6), 517-536. doi: 10.1016/j.jeconbus.2010.08.003

Eugene F Fama, \& Jensen, M. C. (1983). Separation of Ownership and Control. Journal of Law and Economics, XXVI(june).

Fan, Q. (2007). Earnings Management and Ownership Retention for Initial Public Offering Firms theory and Evidence. THE ACCOUNTING REVIEW, 82(1), 27-64.

Filatotchev, I., \& Bishop, K. (2002). Board Composition, Share Ownership, and 'Underpricing' Of U.K. Ipo Firms. Strategic Management Journal, 23, 941-955. doi: 10.1002/smj.269

Grinblatt, M., \& Hwang, C. Y. (1989). Signalling And The Pricing Of New Issues. THE JOURNAL OF FINANCE, Xliv(2 june), 393-420.

Gul, S., Muhammad, S., Nasir, R., \& Farman, A. (2012). Agency cost, corporate governance and ownership structure: the case of Pakistan. International Journal of Business and Social Science, 3(9), 268-277.

Handa, R., \& Singh, B. (2015). Women directors and IPO underpricing: evidence from Indian markets. Gender in Management: An International Journal,, 30(3), 186 - 205.

Hearn, Bruce. 2011. "The impact of corporate governance measures on the performance of West African IPO firms." Emerging Markets Review no. 12:130-151. doi: 10.1016/j.ememar.2011.02.004.

He, L., Cordeiro, J. J., \& Shaw, T. S. (2015). CEO power, equity ownership and underwriter reputation as determinants of lockup period length. Management Research Review,, $35(5), 438-458$.

Hermalin, B. E., \& Weisbach, M. S. (2003). Boards of Directors as an Endogenously Determined Institution: A Survey of the Economic Literature. FRBNY Economic Policy Review, april, 7-26.

Howton, S. D., Howton, S. W., \& Olson*, G. T. (2001). Board Ownership and IPO Returns. Journal Of Economics And Finance, 9(25), 100-114.

Hull, R., Walker, R., \& Sungkyu Kwak. (2013). "IPO valuation and insider manipulation of R\&D". Managerial Finance, 39(10), 888 - 914.

Jensen, M. C., \& Meckling, W. H. (1976). Theory of the Firm: Managerial Behavior,Agency Costs and Ownership Structure Journal of Financial Economics (Vol. 3, pp. 305-360).

Jigao Zhua, Ye, K., Tucker, J. W., \& Chan, K. J. C. (2016). Board hierarchy, independent directors, and firmvalue: Evidence from China. Journal of Corporate Finance, 41, 262 279. doi: 10.1016/j.jcorpfin.2016.09.009 
Keasey, K., \& McGuinness, P. (1992). An Empirical Investigation of the Role of Signalling in the Valuation of Unseasoned Equity Issues. Accounting and Business Research, 22(86), 133-142. doi: 10.1080/00014788.1992.9729428

Kuntara Pukthuanthong-Le, \& Walker, T. (2008). Family Control, Underwriter Prestige, and IPO Underpricing: A Cross Country Analysis. Multinational Business Review, 16 (2 pp), $1-42$

Leland, H. E., \& Pyle, D. H. (1977). Informational Asymmetries, Financial Structure, And Financial Intermediation. THE JOURNAL OF FINANCE, XXXIL 2(2 May), 371-387.

Leone, A. J., Rock, S., \& Willenborg, M. (2007). Disclosure of Intended Use of Proceeds and Underpricing in Initial Public Offerings. Journal of Accounting Research, 45(1), 111153.

Li, M., Zheng, S. X., \& Melancon, M. V. (2005). Underpricing, share retention, and the IPO aftermarket liquidity. International Journal of Managerial Finance,, 1(2), 76 - 94.

Lin, Chih-Pin, dan Cheng-Min Chuang. 2011. "Principal-Principal Conflicts and IPO Pricing in an Emerging Economy." Corporate Governance: An International Review no. 19 (6):585-600. doi: 10.1111/j.14678683.2011.00870.x

Maheshwari, Yogesh, dan Khushbu Agrawal. 2015. "Impact of IPO grading on earnings management." Journal of Financial Reporting and Accounting no. 13 (2):142 - 158.

Michel, A., Oded, J., \& Shaked, I. (2014). Ownership structure and performance: Evidence from the public float in IPOs. Journal of Banking \& Finance, 40, 54-61. doi: 10.1016/j.jbankfin.2013.11.018

Mnif., A. (2010). Board Of Directors And The Pricing Of Initial Public Of-Ferings (Ipos): Does The Existence Of A Properly Structured Board Matter? Evidence From France.

Mohd-Rashid, Abdul-Rahim, \& N, C.-Y. (2016). Shareholder Retention Influence on the Flipping Activity of Malaysian IPOs. Pertanika J. Soc. Sci. \& Hum, 24(s), 133 - 144.

Mousa, F.-T., Marlin, D., \& Ritchie, W. J. (2013). Configurations of slack and their performance implications: an examination of high-tech IPOs. Management Decision, 51(2), $225-247$.

Mousa, F.-T., Ritchie, W. J., \& Reed, R. (2014). Founder-CEO board involvement and optimal IPO valuation. Management Decision, 52(3), 642 - 657.

Nakano, M., \& Nguyen, P. (2012). Board Size and Corporate Risk Taking: Further Evidence from Japan. Corporate Governance: An International Review, 20(4), 369-387. doi: 10.1111/j.1467-8683.2012.00924.x

Nikbakht, E., Shahrokhi, M., \& Robert Martin, J. (2007). IPO Pricing and Executive Compensation. International Journal Of Business, 12(3), 321-324.

Ritter, Jay R. 1991. "The Long-Run Performance Of Initial Public Offerings." The Journal Of Finance no. Xlvi (1 March):3-26.

Salloum Charbel, B. E., Samara Georges. (2013). Impact of family involvement in ownership management and direction on financial performance of the Lebanese firms. $i$ n te $r n a$

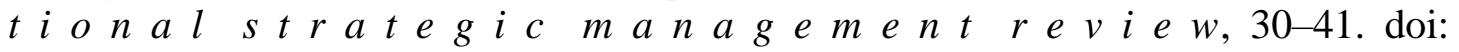
10.1016/j.ism.2013.08.003

Samarakoon, L. P. (2010). The short-run underpricing of initial public offerings in the Sri Lankan stock market $\square$. / J. of Multi. Fin. Manag., 20, 197-213. doi: 10.1016/j.mulfin.2010.07.003

Shleifer, A., \& Vishny, R. W. (1997). A Survey of Corporate Governance. THE JOURNAL OF FINANCE, LII(2), 737-783. 
$\mathrm{Su}, \mathrm{D}$. (2004). Leverage, insider ownership, and the underpricing of IPOs in China. Int. Fin. Markets, Inst. and Money, 14, 37-54. doi: 10.1016/S1042-4431(03)00043-X

Wang, K., \& Iqbal, Z. (2006). Auditor choice, retained ownership, and earnings disclosure for IPO firms. International Journal of Managerial Finance, 2(3), 220 - 240.

Yasser, Q. R., \& Mamun, A. A. (2015). Effects of ownership concentration on firm performance: Pakistani evidence. Journal of Asia Business Studies, 9(2), 162 - 176.

Yatim, P. (2011). Underpricing and Board Structures: An Investigation Of Malaysian Initial Public Offerings (IPOs). Asian Academy Of Management Journal Of Accounting And Finance, 7(1), 73-93.

Yermack, D. (1996). Higher market valuation of companies with a small board of directors. Journal of Financial Economics, 40, 185-211.

Yong Wang, \& Zhang., X. T. (2015). Strategic IPO Underpricing: The Role of Chinese State Ownership" In Value Creation in Multinational Enterprise. . Published online, 09(Maret), 475-495.

Zhijian Xu Libo Xu. (2012). IPO valuation of entrepreneurial firms in China's new growth enterprise market. Journal of Chinese Entrepreneurship, 4(3), 206 - 220.

Zhou, J., \& Lao, L.-J. (2012). Analysis of Influencing Factors of IPO Underpricing in ChiNext. Physics Procedia, 33, 846 - 851. doi: 10.1016/j.phpro.2012.05.144

Zimmerman, M. A. (2008). The Influence of Top Management Team Heterogeneity on the Capital Raised through an Initial Public Offering. Entrepreneurship Theory And Practice, 391-414. 